\title{
Degeneration and Atrophy
}

National Cancer Institute

\section{Source}

National Cancer Institute. Degeneration and Atrophy. NCI Thesaurus. Code C120874.

A finding that generally has features of degeneration and atrophy. 